\title{
Polycyclitols: synthesis of novel carbasugar and conduritol analogues as potential glycosidase inhibitors
}

\author{
Goverdhan Mehta* and Senaiar S. Ramesh \\ Department of Organic Chemistry, Indian Institute of Science, Bangalore 560 012, India
}

\begin{abstract}
Stereoselective syntheses of a new family of hydrindane based bicyclitols with seven hydroxyl groups in a diverse stereochemical array have been accomplished from readily available building-blocks. One of the bicyclitols $\mathbf{1 2}$ has been found to exhibit moderate $\alpha$-glucosidase inhibitory activity in enzymatic assays.
\end{abstract}

Inhibitors of glycosidases or glycomimics have received considerable attention in the past two decades or so as they are potential therapeutic agents for the treatment of diseases related to metabolic disorders of carbohydrates such as diabetes, cancer, AIDS and viral infections, where glycoprotein processing is crucial. $^{1,2} \mathrm{~A}$ range of carbo- and heterocyclic analogues of carbohydrates that resemble monosaccharides in shape, size and functionalization, and can act as transition state mimics but formally lack a glycosidic linkage, have been devised and their glycosidase inhibitory activities evaluated. ${ }^{1,2}$ In this context, carbasugars 1 (with diverse functionalization and stereochemical features) ${ }^{2}$ and conduritols 2 (six diastereomers designated $\mathrm{A}-\mathrm{F}$ are known $)^{3}$ have generated a great deal of synthetic interest. We have recently introduced polycyclitols (fused polycarbocyclic systems with dense hydroxyl functionalization) like 3-5 as new structural variants embodying the characteristic features present in $\mathbf{1}$ and $2 .^{4,5}$ Among these, one of the diastereomers of $\mathbf{5}$ representing a hybrid structure of $\mathbf{1}$ and $\mathbf{2}$ has shown potent and selective $\alpha$-glucosidase inhibition at $\mu \mathrm{M}$ concentration. $^{4 \mathrm{c}}$ This promising lead motivated us to prepare new bicyclitols related to $\mathbf{5}$, but having subtle structural and conformational divergence. Herein, we report the stereo- and regioselective synthesis of several bicyclitols based on the hydrindane system $\mathbf{6}$, which can be regarded as an annulated conduritol or carbasugar (see bold portion in 6 corresponding to 1). Our synthetic approaches leading to secured stereochemistry at all the available nine stereogenic centres in the bicyclitols 6 are notable for their brevity and simplicity.<smiles>OCC1CC(O)C(O)C(O)C1O</smiles>

1<smiles>OCC1C(O)C(O)C(O)C2C(O)C(O)C(O)C12</smiles>

4<smiles>OC1C=CC(O)C(O)C1O</smiles>

2<smiles>OC1C(O)C(O)C2C(O)C(O)C(O)C(O)C2C1O</smiles>

5<smiles>OCC1C(O)C(O)C(O)C2C(O)C(O)C(O)C(O)C12</smiles>

3<smiles>OC1C(O)C2C(O)C(O)C(O)C2C1O</smiles>

6

Keywords: cyclitols; carbohydrate mimetics; enzyme inhibitors; osmylation.

* Corresponding author. E-mail: gm@orgchem.iisc.ernet.in 
Readily available Diels-Alder endo-adduct ( \pm )-7 between 5,5-dimethoxy-1,2,3,4-tetrachlorocyclopentadiene and 1,3-cyclopentadiene was stereoselectively elaborated to the triacetate $\mathbf{8}$, as reported previously by us. Acetal deprotection in $\mathbf{8}$ led to the norbornenone derivative 9 which was subjected to thermally induced decarbonylation to deliver the tricyclic diene 10.6 The $C_{\mathrm{s}}$ symmetry of $\mathbf{1 0}$ was revealed through its spectral characteristics and particularly the nine line ${ }^{13} \mathrm{C}$ NMR spectrum $^{6}$ (Scheme 1). Catalytic $\mathrm{OsO}_{4}$ mediated double dihydroxylation in $\mathbf{1 0}$ proceeded quite efficiently to furnish a tetrahydroxy-triacetate $\mathbf{1 1}$ which was devoid of any symmetry. Loss of symmetry during the double dihydroxylation reaction on the diene secured the stereochemistry of 11, which required that the two dihydroxylations on $\mathbf{1 0}$ had occurred from the exo- and endo-face, respectively (Scheme 1). Mild base hydrolysis of triacetate 11 gave the targeted heptahydroxy compound $12 .{ }^{6}$ After full characterization, the bicyclitol $\mathbf{1 2}$ was screened against $\alpha$ - and $\beta$-glucosidases (from Bakers' yeast and almonds, respectively) that accept corresponding $p$-nitrophenylglycosides as substrates. It was observed that 12 exhibited moderate inhibition of $\alpha$ glucosidase with a $K_{\mathrm{i}}$ value of $84 \mu \mathrm{M}$ (cf. $K_{\mathrm{i}}=25.4 \mu \mathrm{M}$ for the well known inhibitor deoxynojirimycin, DNJ). ${ }^{7}$ At $\mathrm{mM}$ concentrations, $\mathbf{1 2}$ exhibited no significant inhibition against $\beta$-glucosidase, indicating selectivity in its response towards the two glucosidases.

The activity observed in the case of $\mathbf{1 2}$ motivated us to undertake the synthesis of its diastereomeric derivatives, as the stereochemical disposition of the hydroxyl arrays is known to modulate inhibitory activity and selectivity. The starting material for the synthesis of the stereochemical siblings of $\mathbf{1 2}$ was the readily available endo-tricyclic enone 13 that was elaborated to $\mathbf{1 4}$, as described previously by us. ${ }^{4 a}$ Careful ketal deprotection in $\mathbf{1 4}$ led to the norbornenone derivative 15. Thermal activation of $\mathbf{1 5}$ resulted in the elimination of $\mathrm{CO}$ and the bicyclic diene $\mathbf{1 6}$ was realized quite smoothly. Singlet oxygen addition to the cyclohexadiene moiety present in $\mathbf{1 6}$ resulted in [4+2]-cycloaddition and endoperoxide $17^{6}$ was the sole product of the reaction, with ${ }^{1} \mathrm{O}_{2}$ addition occurring from the preferred convex face of the molecule (Scheme 2). Lithium aluminium hydride reduction of the endoperoxide $\mathbf{1 7}$ led to the ene-diol 18 along the expected lines. The cyclohexene moiety in 18 on subjecting to catalytic $\mathrm{OsO}_{4}$ dihydroxylation gave a 3:1 mixture of $\mathbf{1 9}$ and $\mathbf{2 0}$ with preferred addition from the convex face. The stereochemical outcome is quite interesting in the sense that the preferred dihydroxylation in allylic alcohols from the anti-face is overwhelmed by the steric preference for the convex face in $\mathbf{1 8}$ and syn addition product $\mathbf{1 9}$ is obtained as the major product. Separation and stereochemical assignment to $\mathbf{1 9}$ and $\mathbf{2 0}$ followed from their conversion to the tris-acetonide $\mathbf{2 1}$ and bis-acetonide $\mathbf{2 2}$, respectively (Scheme 2). Hydrolysis of acetonide moieties in $\mathbf{2 1}$ and $\mathbf{2 2}$ furnished the diastereomeric hepta-hydroxy hydrindanes $\mathbf{2 3}$ and $\mathbf{2 4}$, respectively, and these were duly characterized. ${ }^{6}$

In another stereochemical variation, bicyclohexadiene 16 was directly subjected to $\mathrm{OsO}_{4}$ mediated double dihydroxylation to furnish pentahydroxy compound 25, whose stereochemistry follows from the incisive analysis of its spectral data and through analogy with $\mathbf{1 1}$ (Scheme 1). Hydrolysis of the acetonide protective group in $\mathbf{2 5}$ delivered $\mathbf{2 6}^{6,8}$ (Scheme 3 ).

Bicyclitols 23, 24 and 26 were also subjected to enzymatic assays with $\alpha$ - and $\beta$-glucosidases following the protocols similar to that described above for 12. However, so far we have not encountered any significant inhibitory activity in these compounds. This observation further underscores the importance of the stereochemical disposition of the hydroxyl groups in fine tuning the activity and provides impetus for developing synthetic routes to other diastereomers of these novel bicyclitols.

In conclusion, we have outlined the syntheses of a new family of bicyclitols based on the hydrindane framework, with stereocontrol at all the nine stereogenic centres. One of these bicyclitols 12, a carbasugar/con-

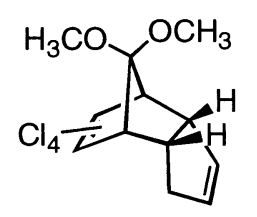

(土) 7

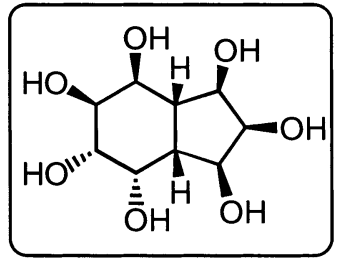

(土) 12

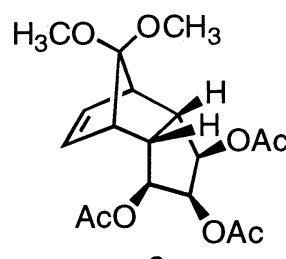

8

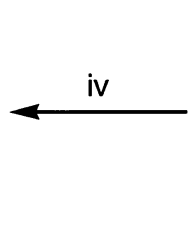

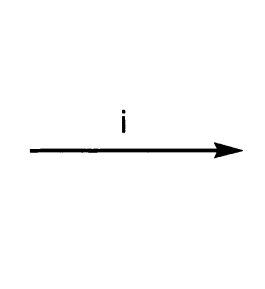

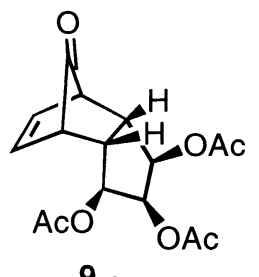

9 ii

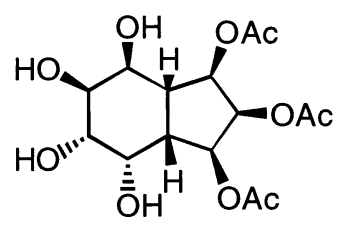

11

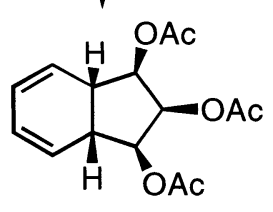

10

Scheme 1. Reagents and conditions: (i) Acetone, amberlyst-15, 89\%; (ii) $\mathrm{C}_{6} \mathrm{H}_{5} \mathrm{NO}_{2}$, heat, $160^{\circ} \mathrm{C}, 50 \%$; (iii) $\mathrm{OsO}_{4}$ (cat.), $\mathrm{NMMO}$, $\mathrm{Me}_{2} \mathrm{CO}: \mathrm{H}_{2} \mathrm{O}: t-\mathrm{BuOH}$ (5:5:2), 88\%; (iv) aq. $\mathrm{NaOH}, 60 \%$. 


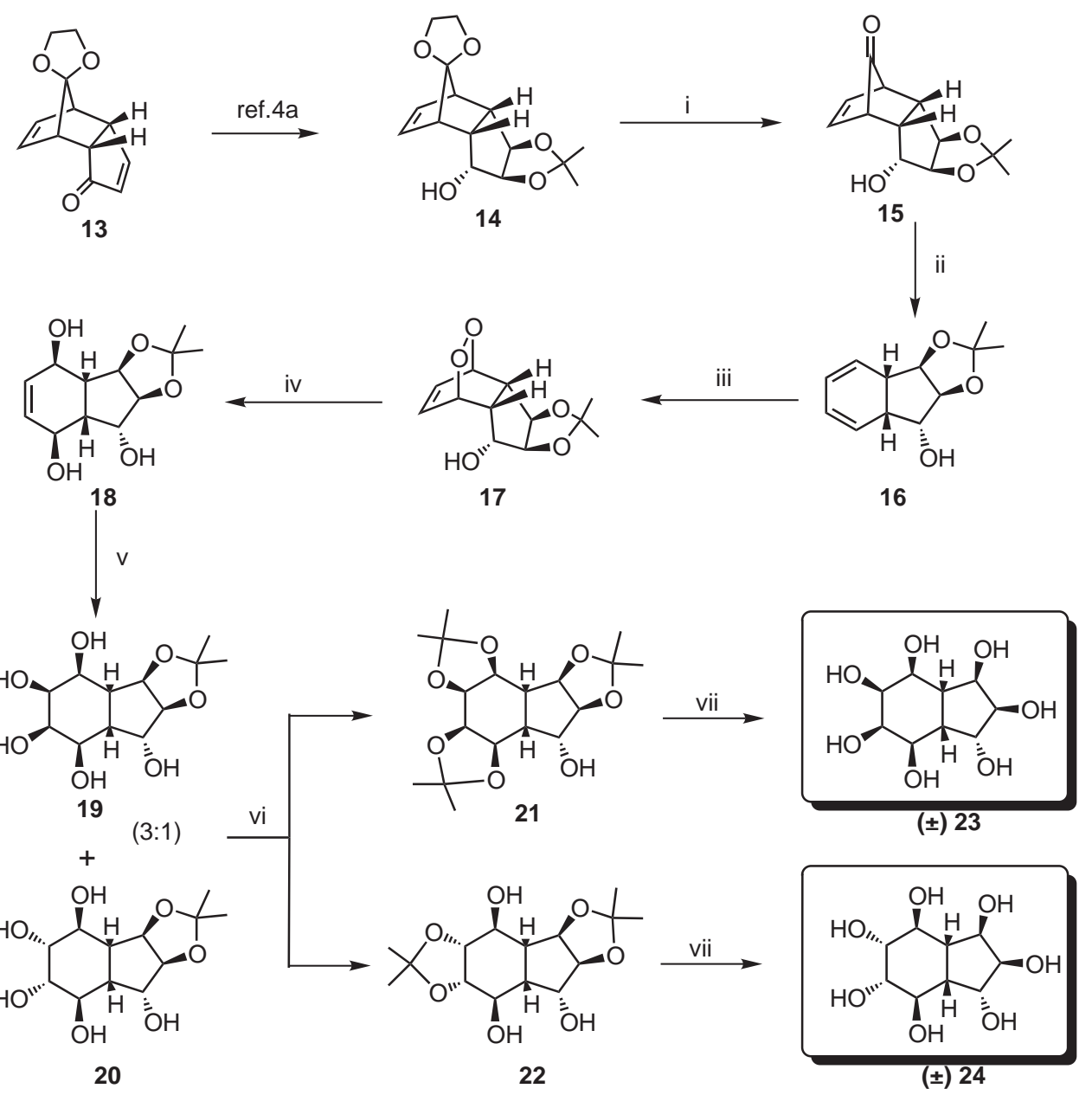

Scheme 2. Reagents and conditions: (i) Acetone, amberlyst- 15 , reflux, $81 \%$; (ii) $\mathrm{C}_{6} \mathrm{H}_{5} \mathrm{NO}_{2}$, heat, $160^{\circ} \mathrm{C}, 67 \%$; (iii) ${ }^{1} \mathrm{O}_{2}, h v$, methylene blue, $\mathrm{CHCl}_{3}, 90 \%$; (iv) $\mathrm{LiAlH}_{4}$, THF, 54\%; (v) $\mathrm{OsO}_{4}$ (cat.), NMMO, $\mathrm{Me}_{2} \mathrm{CO}: \mathrm{H}_{2} \mathrm{O}: t$ BuOH (5:5:2), 83\%; (vi) acetone, amberlyst-15, followed by $\mathrm{SiO}_{2}$-gel separation, $62 \%$ for $\mathbf{2 1}$ and $21 \%$ for 22, from 18; (vii) $30 \% \mathrm{CF}_{3} \mathrm{COOH}, 92 \%$ for $\mathbf{2 3}$ and $88 \%$ for $\mathbf{2 4}$.

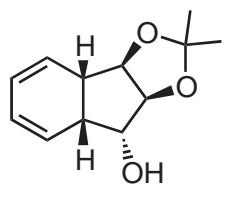

16<smiles>CC1(C)O[C@H]2[C@@H](O)[C@H]3[C@H](O)[C@H](O)[C@@H](O)[C@H](O)[C@H]3[C@H]2O1</smiles>

25

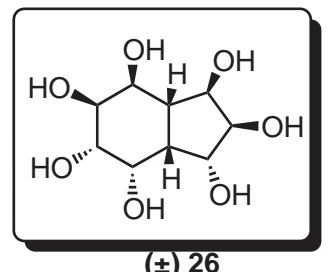

$( \pm) 26$

Scheme 3. Reagents and conditions: (i) $\mathrm{OsO}_{4}$ (cat.), $\mathrm{NMMO}, \mathrm{Me}_{2} \mathrm{CO}: \mathrm{H}_{2} \mathrm{O}: t \mathrm{BuOH}(5: 5: 2), 83 \%$; (ii) $30 \% \mathrm{CF}_{3} \mathrm{COOH}, 89 \%$.

duritol analogue, exhibits moderate and selective $\alpha$-glucosidase inhibitory activity.

\section{Acknowledgements}

We thank the Chemical Biology Unit of JNCASR for support of this research. High field NMR data reported here was obtained through the help of SIF at IISc. S.S.R. thanks CSIR for the award of a Research Fellowship.

\section{References}

1. Recent reviews: (a) Hughes, A. B.; Rudge, A. J. Nat. Prod. Rep. 1994, 135; (b) Jacob, G. S. Curr. Opin. Struct. Biol. 1995, 605; (c) Ganem, B. Acc. Chem. Res. 1996, 29, 340; (d) Bols, M. Acc. Chem. Res. 1998, 31, 1; (e) Heighten, T. D.; Vasella, A. T. Angew. Chem., Int. Ed. 1999, 38, 750; (f) Sears, P.; Wong, C.-H. ibid. 1999, 38, 2300.

2. (a) Suami, T. Top. Curr. Chem. 1990, 154, 257; (b) Ferrier, R. J.; Middleton, S. Chem. Rev. 1993, 93, 2779; (c) Hudlicky, T.; Entwistle, D. A.; Pitzer, K. K.; Thorpe, A. J. Chem. Rev. 1996, 96, 1195; (d) Martinez-Grau, A.; Marco- 
Contelles, J. Chem. Soc. Rev. 1998, 27, 155; (e) Landais, Y. Chimia 1998, 52, 104; (f) Johnson, C. R. Acc. Chem. Res. 1998, 31, 333; (g) Berecibar, A.; Grandjean, C.; Siriwardena, A. Chem. Rev. 1999, 99, 779.

3. (a) Balci, M.; Sutbeyaz, Y.; Secen, H. Tetrahedron 1990, 46, 3715; (b) Carless, H. A. J. Tetrahedron: Asymmetry 1992, 3, 795; (c) Balci, M. Pure Appl. Chem. 1997, 69, 97.

4. (a) Mehta, G.; Reddy, D. S. Tetrahedron Lett. 1999, 40, 9137; (b) Mehta, G.; Reddy, D. S.; Ramesh, S. S.; Tatu, U. Tetrahedron Lett. 1999, 40, 9141; (c) Mehta, G.; Ramesh, S. S. Chem. Commun. 2000, 2429.

5. For a few related examples of syntheses of annulated conduritols, see: (a) Billington, D. C.; Perron-Sierra, F.; Picard, I.; Beaubras, S.; Duhault, J.; Espinal, J.; Challal, S. Bioorg. Med. Chem. Lett. 1994, 4, 2307; (b) Kara, Y.; Balci, M.; Bourne, S. A.; Watson, W. H. Tetrahedron Lett. 1994, 35, 3349; (c) Desjardins, M.; Lallemand, M. C.; Hudlicky, T. Abboud, K. A. Synlett 1997, 728.

6. All new compounds reported here were racemic and were characterized on the basis of their spectral data $\left({ }^{1} \mathrm{H}\right.$ and ${ }^{13} \mathrm{C}$ NMR, IR, mass). Selected spectral data. 10: ${ }^{1} \mathrm{H}$ NMR $\left(300 \mathrm{MHz}, \mathrm{CDCl}_{3}\right): \delta 5.88-5.84(\mathrm{~m}, 2 \mathrm{H}), 5.70-5.66(\mathrm{~m}$, $2 \mathrm{H}), 5.25(\mathrm{t}, 1 \mathrm{H}, J=4.5 \mathrm{~Hz}), 5.09-5.05(\mathrm{~m}, 2 \mathrm{H}), 3.10$ (br s, 2H), $2.09(\mathrm{~s}, 3 \mathrm{H}), 2.07(\mathrm{~s}, 6 \mathrm{H}) ;{ }^{13} \mathrm{C} \mathrm{NMR}(75 \mathrm{MHz}$, $\mathrm{CDCl}_{3}$ ): $\delta 170.1$ (2C), 170.0, 124.7 (2C), 122.4 (2C), 78.0 (2C), 69.5, 38.9 (2C), 20.7, 20.6. 11: ${ }^{1} \mathrm{H}$ NMR (300 MHz, $\left.\mathrm{D}_{2} \mathrm{O}\right): \delta 5.38(\mathrm{t}, 1 \mathrm{H}, J=6.3 \mathrm{~Hz}), 5.27(\mathrm{dd}, 1 \mathrm{H}, J=6.3,18.0$ $\mathrm{Hz}), 5.08$ (t, 1H, $J=7.0 \mathrm{~Hz}), 3.97($ br s, 1H), $3.90(\mathrm{t}, 1 \mathrm{H}$, $J=4.0 \mathrm{~Hz}), 3.78(\mathrm{dd}, 1 \mathrm{H}, J=7.9,3.7 \mathrm{~Hz}), 3.66(\mathrm{dd}, 1 \mathrm{H}$, $J=8.2,2.8 \mathrm{~Hz}), 2.52(\mathrm{~m}, 1 \mathrm{H}), 2.40$ (br s, $1 \mathrm{H}), 1.99$ (s, 6H), $1.95(\mathrm{~s}, 3 \mathrm{H}) ;{ }^{13} \mathrm{C}$ NMR $\left(75 \mathrm{MHz}, \mathrm{D}_{2} \mathrm{O}\right): \delta$ 174.2, 174.1, 173.2, 75.0, 74.7, 71.7, 71.1, 70.0, 69.0, 68.6, 45.6, 43.5, 20.9, 20.8, 20.5. 12: ${ }^{1} \mathrm{H}$ NMR (300 MHz, $\left.\mathrm{D}_{2} \mathrm{O}\right): \delta 4.13(\mathrm{t}$, $1 \mathrm{H}, J=4.3 \mathrm{~Hz}), 3.98-3.85(\mathrm{~m}, 4 \mathrm{H}), 3.73(\mathrm{dd}, 1 \mathrm{H}, J=7.3$, $4.0 \mathrm{~Hz}), 3.61(\mathrm{dd}, 1 \mathrm{H}, J=7.6,2.8 \mathrm{~Hz}), 2.21-2.08(\mathrm{~m}, 2 \mathrm{H})$; ${ }^{13} \mathrm{C}$ NMR $\left(100 \mathrm{MHz}, \mathrm{D}_{2} \mathrm{O}\right): \delta 76.4,75.0,74.6,74.4,73.1$, 71.9, 71.8, 48.3, 47.2. 23: ${ }^{1} \mathrm{H}$ NMR (300 MHz, $\left.\mathrm{D}_{2} \mathrm{O}\right): \delta$ 4.05-4.01 (m, 1H), 3.89-3.85 (m, 2H), 3.74-3.70 (m, 3H), 3.63-3.61 (m, 1H), $2.46(\mathrm{q}, 1 \mathrm{H}, J=7.0 \mathrm{~Hz}), 2.15-2.09(\mathrm{~m}$, $1 \mathrm{H}) ;{ }^{13} \mathrm{C}$ NMR $\left(75 \mathrm{MHz}, \mathrm{D}_{2} \mathrm{O}\right): \delta 78.9,77.6,72.7,72.2$, 71.5, 70.8, 70.1, 47.5, 41.0. 24: ${ }^{1} \mathrm{H}$ NMR (300 MHz, $\left.\mathrm{D}_{2} \mathrm{O}\right)$ : $\delta 4.10(\mathrm{t}, 1 \mathrm{H}, J=5.8 \mathrm{~Hz}), 4.00(\mathrm{t}, 1 \mathrm{H}, J=5.4 \mathrm{~Hz}), 3.87-$ $3.80(\mathrm{~m}, 2 \mathrm{H}), 3.75-3.70(\mathrm{~m}, 1 \mathrm{H}), 3.66-3.61(\mathrm{~m}, 2 \mathrm{H}), 2.40$ 2.32 (q like m, 1H), 1.97-1.90 (q like $\mathrm{m}, 1 \mathrm{H}) ;{ }^{13} \mathrm{C} \mathrm{NMR}$ $\left(75 \mathrm{MHz}, \mathrm{D}_{2} \mathrm{O}\right): \delta 77.8,77.1,74.0,73.2,72.3,72.0,68.8$, 48.6, 44.2. 26: ${ }^{1} \mathrm{H}$ NMR (300 MHz, $\left.\mathrm{D}_{2} \mathrm{O}\right): \delta 4.19-4.15(\mathrm{~m}$, $1 \mathrm{H}), 4.01-3.81(\mathrm{~m}, 4 \mathrm{H}), 3.68-3.64(\mathrm{~m}, 1 \mathrm{H}), 3.61-3.56(\mathrm{~m}$, 1H), 2.40-2.33 (m, 1H), 2.13-2.07 (m, 1H); ${ }^{13} \mathrm{C}$ NMR (75 $\left.\mathrm{MHz}, \mathrm{D}_{2} \mathrm{O}\right): \delta 77.9,77.2,73.6,72.9,72.3,68.4,67.4,45.9$, 41.8 .

7. Each enzymatic assay contained $\alpha$ - or $\beta$-glucosidase $(0.1-$ $1.0 \mathrm{U} / \mathrm{ml}$ ), compounds 12, 23, 24 and 26 in water and the corresponding $p$-nitrophenylglycosides $(2-3 \mathrm{mM})$ at a $\mathrm{pH}$ and temperature optimum for the enzyme. $K_{\mathrm{i}}(\mu \mathrm{M})$ values were determined using Lineweaver-Burk plots of the inhibition data.

8. Stereostructure $\mathbf{2 6}$ is the most likely formulation and is derived on the basis of analogy with 11, the inherent steric preference of the cis-hydrindane moiety and the directing influence of the $\alpha$-hydroxy group in $\mathbf{1 6}$. 